\title{
Synthesis of Optically Active Oxazolines by an Organocatalytic Isocyanoacetate Aldol Reaction with $\alpha$-Keto Esters
}

\author{
Fei Wang \\ Jiean Chen* \\ Yong Huang* \\ Key Laboratory of Chemical Genomics, School of Chemical \\ Biology and Biotechnology, Peking University, Shenzhen \\ Graduate School, Shenzhen, 518055, P. R. of China \\ chenja@pkusz.edu.cn \\ huangyong@pkusz.edu.cn
}
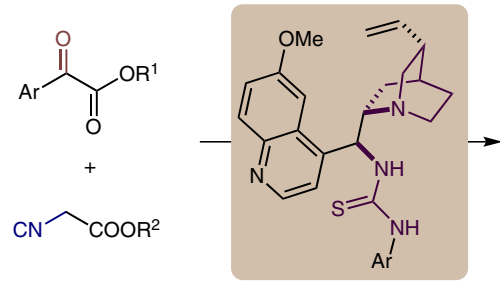

bifunctional cat. (10 mol\%)

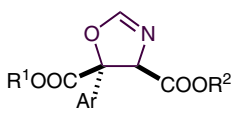

- $\alpha$-keto ester \& $\alpha$-isocyanoacetate - oxazoline with chiral centers

- versatile skeleton for $\beta$-hydroxy- $\alpha$-amino acid

- 12 examples, up to $84 \%$ yield, $97 \%$ ee
Received: 27.12.2016

Accepted after revision: 25.01.2017

Published online: 23.02 .2017

DOI: 10.1055/s-0036-1588718; Art ID: st-2016-b0875-c

Abstract An enantioselective [3+2] cyclization is reported for the construction of a chiral oxazoline skeleton in moderate yield and up to $97 \%$ ee. The reactivity and stereochemical discrimination originate from the noncovalent interaction and orientation of a bifunctional catalyst. The novel combination of an $\alpha$-keto ester and an $\alpha$-isocyanoacetate establishes an oxazoline which could be a potential chiral ligand for metalmediated catalysis, and also could be easily converted into an optically active $\beta$-hydroxy- $\alpha$-amino acid.

Key words organocatalysis, bifunctional catalyst, noncovalent interaction, asymmetric cyclization, chiral oxazoline

Nitrogen-containing heterocycles are important in pharmaceutical investigations, especially for small-molecule drug design. ${ }^{1}$ Aimed at target skeletons of this sort, $\alpha-$ isocyanoacetate has been frequently used as versatile synthon providing dipolar reactivity in a $[3+2]$ cyclization process. ${ }^{2}$ Mediated by organocatalysis, several prominent manipulations have been used for the construction of analogues of pyrrole $^{3}$ and imidazole. ${ }^{4}$ However, the straightforward assembly of optically active oxazolines, which act as ligands for transition metals and are the core framework in numerous natural products, is highly dependent on chiral metal complexes. In 1986, Ito and Hayashi reported the first asymmetric aldol-type reaction for $\alpha$-isocyanoacetate using a chiral $\mathrm{Au}(\mathrm{I})$ complex. ${ }^{5}$ Subsequent investigations focused on disparate transition metal catalyst systems and often led to the formation of trans-substituted oxazolines. ${ }^{6}$ In 2011 Dixon et al. utilized a chiral amino phosphine $\mathrm{Ag}(\mathrm{I})$ complex to obtain oxazolines with excellent cis selectivity. ${ }^{7}$ In sharp contrast, the organocatalytic variant for such conversions has been studied and only a single example was presented by Gong et al. ${ }^{8}$ There has been no report of the combination involving a ketone group, which would afford direct access to oxazolines bearing one or two quaternary asymmetric centers. In this paper, we describe the first asymmetric aldol-type transformation of $\alpha$-keto esters with $\alpha$-isocyanoacetate catalyzed by a thiourea/amine bifunctional catalyst and leading to a precursor of $\beta$-hydroxy- $\alpha$-amino acids. ${ }^{5 a-c, 7,9}$

We began by evaluating the efficiency of the bifunctional catalyst system. ${ }^{10}$ Progress in noncovalent catalysis furnishes findings, abundant and well-documented, concerning versatile methodologies and selectivities. ${ }^{11}$ With thiourea/amine-type bifunctional catalysts, the Brønsted basicity of a tertiary amine affords the activation energy for reaction with nucleophilic compounds and simultaneously the thiourea moiety acts as a hydrogen donor to interact with the corresponding electrophile. ${ }^{12}$ This cooperative mode takes advantage of both the substrate proximity effect and a sterically well-defined transition state rendering high synergy to the catalysis. We hypothesized that the dual carbonyl groups of $\alpha$-keto esters would permit a wellorganized cyclic interaction with the thiourea moiety of the bifunctional catalyst, as shown in Scheme 1. Simultaneously, the acidic $\mathrm{C}-\mathrm{H}$ bond of $\alpha$-isocyanoacetate spontaneously enters into a noncovalent interaction with the alkaline site and interacts intramolecularly with the keto group of the $\alpha$-keto ester.

The inception of the aldol-cyclization cascade is initiated by the reaction of ethyl phenylglyoxylate (1a) with methyl isocyanoacetate (2a) which is promoted by various thiourea amines. Takemoto's catalyst (3a; Table 1, entry 1), the simplest bifunctional analogue of chiral 1,2-diaminocyclohexane, delivers fair asymmetric induction along with moderate differentiation of diastereoisomers. The results indicate that thioureas containing a strong basic tertiary amine two carbon atoms removed from the thiocarbonyl group could lead to activation and the resulting stereochemistry. The comparable structure in the cinchona alka- 


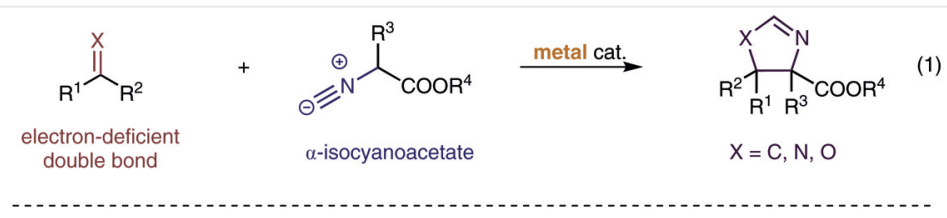

(1)

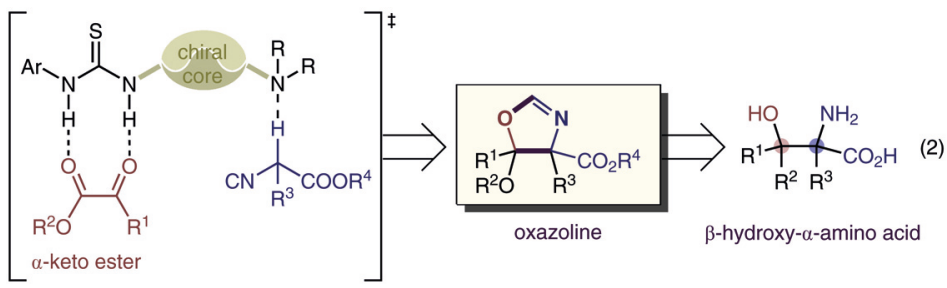

Scheme $1 \alpha$-Keto ester for chiral oxazoline skeleton

loids ( $\mathbf{3 c}-\mathbf{g}$ ) was systematically investigated in the reaction and the essential role of the thiourea moiety was also evaluated (3b). Catalysts lacking thiourea can nevertheless catalyze the oxazoline synthesis, but with noticeably diminished enantioselectivity and yield (Table 1, entry 2, 48\% yield, $33 \%$ ee). The aryl substituents of the thiourea group demonstrate no obvious discrepancy and promote the cyclization with moderate efficiency and enantioselectivity (entries 3 and 4, Table 1, 68\% ee vs. 76\% ee). In a brief screening of the solvent system, toluene was identified as a suitable solvent, delivering acceptable reactivity and selectivity (Table 1, entries 8 and 9).

The substituent effect was evaluated by modifying the $R^{1}, R^{2}$ and $R^{3}$ groups in the starting materials. The substituent in the $\alpha$-position of the isocyanoacetate $\left(R^{3}\right)$ triggered selectivity which might result from excessive crowding in the transition state (entry 10, Table 1; methyl substituent for $53 \%$ ee). When manipulating the steric size of ester groups in the isocyanoacetates, a proportional increase of enantioselectivity indicates that the bulky tert-butyl ester could enhance the facial discrimination and generate an appreciable ee value (entries 9,11 , and 12 in Table 1; 79\% ee vs. $84 \%$ ee vs. $94 \%$ ee, respectively). On the other hand, the $\alpha$-keto esters can tolerate alkyl groups $\left(\mathrm{R}^{1}\right)$ of various sizes with no effect on the enantioselectivity (Table 1, entries 13 and 14). The absolute configurations of the thiourea and quinuclidine moieties were found to control the steric orientation of the transition state and the reaction furnished the desired product with determinable conformation. The same reactions for cinchonidine (3e), quinidine (3f) and cinchonine (3g) showed no significant difference in both catalytic ability and steric discrimination (Table 1, entries 15-17). Catalysts $\mathbf{3 f}$ and $\mathbf{3 g}$ generated the desired product with a structure which is the mirror image of that in $\mathbf{3 c}$. In view of the experimental data and the demonstrated catalytic model, the absolute configuration of the title product was assigned and is shown in Scheme 2.

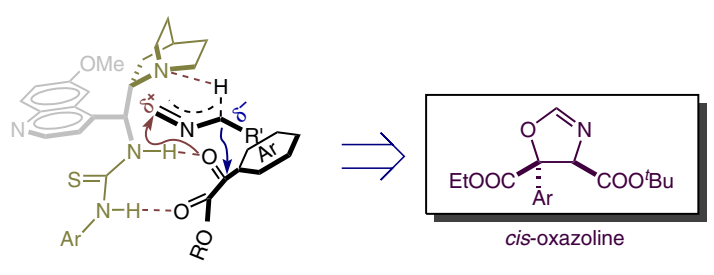

Scheme 2 Proposed transition sate for cis-oxazoline

Under the optimized reaction conditions, diverse aromatic $\alpha$-keto esters were examined and the corresponding oxazolines were synthesized in good yields and with excellent ee values. ${ }^{13}$ As shown in Table 2, ethyl phenylglyoxylate structures containing electron-donating substituents (Me, $\mathrm{OMe}$ ) or electron-withdrawing groups $(\mathrm{F}, \mathrm{Cl}, \mathrm{Br})$ gave the corresponding products with appreciable enantioselectivity (Table 2, entries 2-9). Different patterns of substituents ( $m$ and $p$-) of substituents with different electronic characteristics are tolerated in the reaction. Compounds with a multisubstituted aryl group also performed well giving an excellent ee value for the title oxazoline (entry 10). Furthermore, $\alpha$-keto esters with a heteroaromatic ring and a fused ring can also be converted smoothly into the desired products with appropriate selectivity (Table 2, entries 11 and 12).

Derived from Nuclear Overhauser Effect Spectroscopy (NOESY) analysis (cis product) ${ }^{14}$ and the well-understood interaction pattern between the thiourea moiety and $\alpha$-keto ester, ${ }^{15}$ a proposed transition state is shown in Scheme 2 . The ester carbonyl group of the $\alpha$-keto ester enjoys an $\mathrm{H}$-bonding interaction with the $\mathrm{N}$ atom bearing an aryl group and the ketone carbonyl interacts with the residual $\mathrm{N}$ atom of the thiourea. The nucleophilic $\alpha$-isocyanoacetate is activated by the quinuclidine moiety and attacks from above the rigid ring system. As a consequence, the substitu- 
Table 1 Reaction Optimization

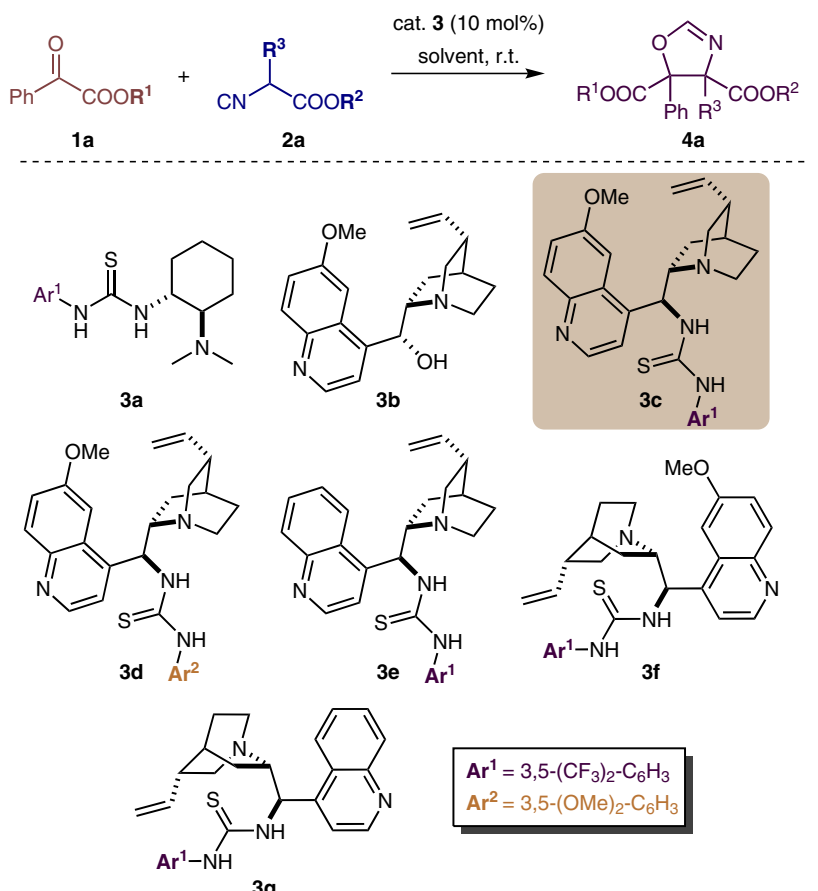

\begin{tabular}{|c|c|c|c|c|c|c|}
\hline \multirow{2}{*}{$\frac{\text { Entry }}{1}$} & \multirow{2}{*}{$\begin{array}{c}\text { Cat. } \\
3 a\end{array}$} & \multirow{2}{*}{$\frac{R^{1}, R^{2}, R^{3}}{\text { Et, Me, } H(\mathbf{2 a})}$} & \multirow{2}{*}{$\begin{array}{l}\text { Solvent } \\
\mathrm{CH}_{2} \mathrm{Cl}_{2}\end{array}$} & \multicolumn{2}{|c|}{ Yield $(\%)^{b} d^{c}$} & \multirow{2}{*}{$\frac{\text { ee }(\%)^{c}}{-70}$} \\
\hline & & & & 53 & $1.8: 1$ & \\
\hline 2 & $3 b$ & Et, Me, H (2a) & $\mathrm{CH}_{2} \mathrm{Cl}_{2}$ & 48 & $1.2: 1$ & 33 \\
\hline 3 & $3 c$ & Et, Me, H (2a) & $\mathrm{CH}_{2} \mathrm{Cl}_{2}$ & 53 & 1.3:1 & 68 \\
\hline 4 & $3 d$ & Et, Me, H (2a) & $\mathrm{CH}_{2} \mathrm{Cl}_{2}$ & 58 & $1.4: 1$ & 76 \\
\hline 5 & $3 d$ & Et, Me, H (2a) & $\mathrm{Et}_{2} \mathrm{O}$ & 56 & $1.4: 1$ & 56 \\
\hline 6 & $3 d$ & Et, Me, H (2a) & THF & trace & n.d. & n.d. \\
\hline 7 & $3 d$ & Et, Me, H (2a) & EtOAc & 36 & $1.5: 1$ & 76 \\
\hline 8 & $3 d$ & Et, Me, H (2a) & toluene & 65 & $2: 1$ & 84 \\
\hline 9 & $3 c$ & Et, Me, H (2a) & toluene & 70 & $2: 1$ & 79 \\
\hline 10 & $3 c$ & Et, Me, $\mathbf{M e ~ ( 2 b ) ~}$ & toluene & 62 & $2: 1$ & 53 \\
\hline 11 & $3 c$ & Et, Et, H (2c) & toluene & 46 & $1.7: 1$ & 84 \\
\hline 12 & $3 c$ & Et, $\boldsymbol{t}$-Bu, H (2d) & toluene & 75 & $2: 1$ & 94 \\
\hline 13 & $3 c$ & $\mathbf{M e}, t-B u, H(2 \mathbf{e})$ & toluene & 67 & $2: 1$ & 93 \\
\hline 14 & $3 c$ & $\mathrm{Bn}, t-\mathrm{Bu}, \mathrm{H}(\mathbf{2 f})$ & toluene & 60 & $1: 1$ & 94 \\
\hline 15 & $3 e$ & Et, $t-B u, H(2 d)$ & toluene & 75 & $2: 1$ & 91 \\
\hline 16 & $3 f$ & Et, $t-B u, H(2 d)$ & toluene & 75 & $2: 1$ & -91 \\
\hline 17 & $3 g$ & Et, $t-B u, H(2 d)$ & toluene & 75 & $2: 1$ & -89 \\
\hline
\end{tabular}

a Unless otherwise noted, all reactions were carried out using $1 \mathrm{a}(0.1 \mathrm{mmol})$, $2 \mathrm{a}(0.12 \mathrm{mmol})$ and the catalyst $(10 \mathrm{~mol} \%)$ in solvent $(0.5 \mathrm{~mL})$ at $26^{\circ} \mathrm{C}$ for $12 \mathrm{~h}$.

${ }^{b}$ Isolated yield after silica gel chromatography.

${ }^{\mathrm{C}}$ The $\mathrm{dr}$ was determined by ${ }^{1} \mathrm{H}$ NMR analysis of the crude mixture.

${ }^{\mathrm{d}}$ Determined by chiral HPLC.
Table 2 Scope of the $\alpha$-Keto Esters ${ }^{\mathrm{a}}$

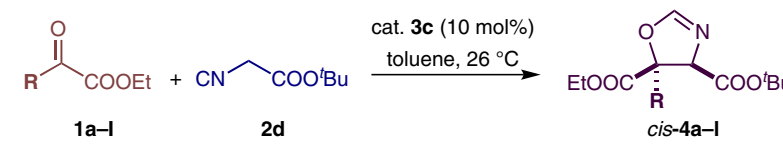

\begin{tabular}{|c|c|c|c|c|}
\hline Entry & $\mathrm{R}$ & Yield (\%) ${ }^{\mathrm{b}}$ & $\mathrm{dr}^{\mathrm{c}}$ & ee $(\%)^{d}$ \\
\hline 1 & $\operatorname{Ph}(\mathbf{1 a})$ & 75 & $2: 1$ & $94\left(81^{\mathrm{e}}\right)$ \\
\hline 2 & 4- $\mathrm{MeC}_{6} \mathrm{H}_{4}(\mathbf{1 b})$ & 73 & $2: 1$ & 94 \\
\hline 3 & $3-\mathrm{MeC}_{6} \mathrm{H}_{4}(\mathbf{1 c})$ & 67 & $2: 1$ & 91 \\
\hline 4 & 4- $\mathrm{MeOC}_{6} \mathrm{H}_{4}(\mathbf{1 d})$ & 78 & $2: 1$ & 97 \\
\hline 5 & $3-\mathrm{MeOC}_{6} \mathrm{H}_{4}(\mathbf{1 e})$ & 72 & $2: 1$ & 94 \\
\hline 6 & $4-\mathrm{FC}_{6} \mathrm{H}_{4}(\mathbf{1 f})$ & 70 & $2: 1$ & 92 \\
\hline 7 & $3-\mathrm{FC}_{6} \mathrm{H}_{4}(\mathbf{1 g})$ & 76 & $2: 1$ & 91 \\
\hline 8 & $4-\mathrm{ClC}_{6} \mathrm{H}_{4}(\mathbf{1 h})$ & 73 & $2: 1$ & 93 \\
\hline 9 & $4-\mathrm{BrC}_{6} \mathrm{H}_{4}(\mathbf{1 i})$ & 77 & $2: 1$ & 91 \\
\hline 10 & 3-F-6- $\mathrm{MeC}_{6} \mathrm{H}_{3}(\mathbf{1} \mathbf{j})$ & 75 & $2: 1$ & 97 \\
\hline 11 & 2-naphthyl (1k) & 84 & $2: 1$ & 90 \\
\hline 12 & 2-thienyl (11) & 80 & $2: 1$ & 89 \\
\hline
\end{tabular}

a Unless otherwise noted, all reactions were carried out using $1 \mathrm{a}-\mathbf{I}(0.1$ $\mathrm{mmol}), 2 \mathrm{~d}(0.12 \mathrm{mmol})$ and $3 \mathbf{c}(10 \mathrm{~mol} \%)$ in toluene $(0.5 \mathrm{~mL})$ at $26^{\circ} \mathrm{C}$ for $24 \mathrm{~h}$.

b Isolated yield after silica gel chromatography.

c The $\mathrm{dr}$ was determined by ${ }^{1} \mathrm{H}$ NMR analysis.

${ }^{d}$ Determined by chiral HPLC.

e The ee value for minor diastereomer.

ent effect is consistent with the experimental data and the diastereoselectivity indicates a stepwise approach for the cyclization.

In summary, an asymmetric isocyanoacetate aldol reaction of $\alpha$-keto esters was realized by a bifunctional catalytic strategy. ${ }^{16}$ Aromatic and heteroaromatic $\alpha$-keto esters are converted into oxazolines in good yield (up to 84\%) and with high enantioselectivity (up to $97 \%$ ee). This provides practical synthetic access to chiral oxazolines which can be precursors to $\beta$-hydroxy- $\alpha$-amino acids. Further efforts are aimed at improving the diastereoselectivity and elucidating the synthetic utility of the reaction in pharmaceutical chemistry.

\section{Acknowledgment}

This work was financially supported by the Science and Technology Innovation Committee of Shenzhen Municipality (JCYJ20160226105602871), the China Postdoctoral Science Foundation (2016M590009), the Guangdong Province Special Branch Program (2014TX01R111) and the Natural Science Foundation of Guangdong Province (2016A030310243).

\section{Supporting Information}

Supporting information for this article is available online at https://doi.org/10.1055/s-0036-1588718. 


\section{References and Notes}

(1) For selected perspective, see: Vitaku, E.; Smith, D. T.; Njardarson, J. T. J. Med. Chem. 2014, 57, 10257.

(2) (a) Wipf, P. Chem. Rev. 1995, 95, 2115. (b) Michael, J. P.; Pattenden, G. Angew. Chem. Int. Ed. 1993, 32, 1. (c) Foster, M. P.; Concepción, G. P.; Caraan, G. B.; Ireland, C. M. J. Org. Chem. 1992, 57, 6671. (d) Aguilar, E.; Meyer, A. I. Tetrahedron Lett. 1994, 35 , 2477. (e) Downing, S. V.; Aguilar, E.; Meyers, A. I. J. Org. Chem. 1999, 64, 826.

(3) For selected examples of construction of chiral analogues of pyrrole, see: (a) Guo, C.; Xue, M. X.; Zhu, M. K.; Gong, L. Z. Angew. Chem. Int. Ed. 2008, 47, 3414. (b) Song, J.; Guo, C.; Chen, P. H.; Yu, J.; Luo, S. W.; Gong, L. Z. Chem. Eur. J. 2011, 17, 7786. (c) Wang, L. L.; Bai, J. F.; Peng, L.; Qi, L. W.; Jia, L. N.; Guo, Y. L.; Luo, X. Y.; Xu, X. Y.; Wang, L. X. Chem. Commun. 2012, 48, 5175. (d) Zhao, M. X.; Wei, D. K.; Ji, F. H.; Zhao, X. L.; Shi, M. Chem. Asian J. 2012, 7, 2777.

(4) For an example of the construction of chiral analogues of imidazole, see: Shao, P. L.; Liao, J. Y.; Ho, Y. A.; Zhao, Y. Angew. Chem. Int. Ed. 2014, 53, 5435.

(5) For the construction of chiral analogues of oxazoline mediated by a chiral $\mathrm{Au}(\mathrm{I})$ complex, see: (a) Ito, Y.; Sawamura, M.; Hayashi, T. J. Am. Chem. Soc. 1986, 108, 6405. (b) Ito, Y.; Sawamura, M.; Hayashl, T. Tetrahedron Lett. 1988, 29, 239. (c) Ito, Y.; Sawamura, H.; Hamashima, H.; Eaura, T.; Hayashi, T. Tetrahedron Lett. 1989, 30, 4681. (d) Pastor, S. D.; Togni, A. J. Am. Chem. Soc. 1989, 111, 2333. (e) Togni, A.; Pator, S. D. J. Org. Chem. 1990, 55, 1649. (f) Hayashi, T.; Sawamura, M.; Ito, Y. Tetrahedron 1992, 48, 1999. (g) Sawamura, M.; Nakayama, Y.; Kato, T.; Ito, Y. J. Org. Chem. 1995, 60, 1727.

(6) For $\operatorname{Ag}(\mathrm{I})$-mediated systems, see: (a) Sawamura, M.; Hamashima, H.; Ito, Y. J. Org. Chem. 1990, 55, 5935. (b) Hayashi, T.; Uozumi, Y.; Yamazaki, A.; Sawamura, M.; Hamashima, H.; Ito, T. Tetrahedron Lett. 1991, 32, 2799. For Pd(II)-mediated system, see: (c) Longmire, J. M.; Zhang, X.; Shang, M. Organometallics 1998, 17, 4374. (d) Motoyama, Y.; Kawakami, H.; Shimozono, K.; Aoki, K.; Nishiyama, H. Organometallics 2002, 21, 3408. (e) Fossey, J. S.; Richards, C. J. Organometallics 2002, 21, 5259. (f) Giménez, R.; Swager, T. M. J. Mol. Catal. A: Chem. 2001, 166, 265. For Pt(II)-mediated system, see: (g) Horne, D. A.; Yakusijin, K.; Büchi, G. Heterocycles 1994, 39, 139. (h) Gorla, F.; Togni, A.; Venazi, L. M.; Albinati, A.; Lianza, F. Organometallics 1994, $13,1607$.

(7) Sladojevich, F.; Trabocchi, A.; Guarna, A.; Dixon, D. J. J. Am. Chem. Soc. 2011, 133, 1710.

(8) Xue, M. X.; Guo, C.; Gong, L. Z. Synlett 2009, 2191.

(9) Soloshonok, V. A.; Kacharov, A. D.; Avilov, D. V.; Ishikawa, K.; Nagashima, N.; Hayash, T. J. Org. Chem. 1997, 62, 3470.

(10) For selected reviews of bifunctional organocatalysis, see: (a) Doyle, A. G.; Jacobsen, E. N. Chem. Rev. 2007, 107, 5713. (b) Dondoni, A.; Massi, A. Angew. Chem. Int. Ed. 2008, 47, 4638. (c) Melchiorre, P.; Marigo, M.; Carlone, A.; Bartoli, G. Angew. Chem. Int. Ed. 2008, 47, 6318. (d) Giacalone, F.; Gruttadauria, M.; Agrigento, P.; Noto, R. Chem. Soc. Rev. 2012, 41, 2406.

(11) For selected examples of H-bonding catalysis, see: (a) Sigman, M. S.; Jacobsen, E. N. J. Am. Chem. Soc. 1998, 120, 4901. (b) Iwabuchi, Y.; Nakatani, M.; Yokoyama, N.; Hatakeyama, S. J. Am. Chem. Soc. 1999, 121, 10219. (c) List, B.; Lerner, R. A.; Barbas, C. F. III J. Am. Chem. Soc. 2000, 122, 2395. (d) Kita, T.; Georgieva, A.; Hashimoto, Y.; Nakata, T.; Nagasawa, K. Angew. Chem. Int. Ed. 2002, 41, 2832. (e) Huang, Y.; Unni, A. K.; Thadani,
A. N.; Rawal, V. H. Nature (London) 2003, 424, 146. (f) Uraguchi, D.; Terada, M. J. Am. Chem. Soc. 2004, 126, 5356. (g) Akiyama, T.; Itoh, J.; Yokota, K.; Fuchibe, K. Angew. Chem. Int. Ed. 2004, 43, 1566. (h) Hoffmann, S.; Seayad, A. M.; List, B. Angew. Chem. Int. Ed. 2005, 44, 7424. (i) Bauer, A.; Westkämper, F.; Grimme, S.; Bach, T. Nature (London) 2005, 436, 1139. (j) Matsui, K.; Takizawa, S.; Sasai, H. J. Am. Chem. Soc. 2005, 127, 3680. (k) Storer, R. I.; Carrera, D. E.; Ni, Y.; MacMillan, D. W. C. J. Am. Chem. Soc. 2006, 128, 84. (l) Nakashima, D.; Yamamoto, H. J. Am. Chem. Soc. 2006, 128, 9626. (m) Hashimoto, T.; Maruoka, K. J. Am. Chem. Soc. 2007, 129, 10054. (n) Uraguchi, D.; Sakaki, S.; Ooi, T. J. Am. Chem. Soc. 2007, 129, 12392. (o) Ishihara, K.; Nakano, K. J. Am. Chem. Soc. 2007, 129, 8930. (p) Kawabata, T.; Muramatsu, W.; Nishio, T.; Shibata, T.; Schedel, H. J. Am. Chem. Soc. 2007, 129, 12890. (q) Hayashi, Y.; Itoh, T.; Aratake, S.; Ishikawa, H. Angew. Chem. Int. Ed. 2008, 47, 2082. (r) For a review, see: Taylor, M. S.; Jacobsen, E. N. Angew. Chem. Int. Ed. 2006, 45,1520 .

(12) For selected reviews of thiourea/amine-type catalysts, see: (a) Chen, Y.; McDaid, P.; Deng, L. Chem. Rev. 2003, 103, 2965. (b) Tian, S.-K.; Chen, Y.; Hang, J.; Tang, L.; McDaid, P.; Deng, L. Acc. Chem. Res. 2004, 37, 621. (c) Palomo, C.; Oiarbide, M.; López, R. Chem. Soc. Rev. 2009, 38, 632. For selected examples, see: (d) Okino, T.; Hoashi, Y.; Takemoto, Y. J. Am. Chem. Soc. 2003, 125, 12672. (e) Calter, M. A.; Orr, R. K.; Song, W. Org. Lett. 2003, 5, 4745. (f) Li, H.; Wang, Y.; Tang, L.; Wu, F.; Liu, X.; Guo, C.; Foxman, B. M.; Deng, L. Angew. Chem. Int. Ed. 2005, 44, 105. (g) Poulsen, T. B.; Alemparte, C.; Saaby, S.; Bella, M.; Jorgensen, K. A. Angew. Chem. Int. Ed. 2005, 44, 2896. (h) Okino, T.; Hoashi, Y.; Furukawa, T.; Xu, X.; Takemoto, Y. J. Am. Chem. Soc. 2005, 127, 119. (i) Vakulya, B.; Varga, S.; Csámpai, A.; Soós, T. Org. Lett. 2005, 7, 1967. (j) Hamza, A.; Schubert, G.; Soós, T.; Pápai, I. J. Am. Chem. Soc. 2006, 128, 13151. (k) Connon, S. J. Chem. Eur. J. 2006, 12, 5418. (l) Kojima, S.; Suzuki, M.; Watanabe, A.; Ohkata, K. Tetrahedron Lett. 2006, 47, 9061. (m) Johansson, C. C. C.; Bremeyer, N.; Ley, S. V.; Owen, D. R.; Smith, S. C.; Gaunt, M. J. Angew. Chem. Int. Ed. 2006, 45, 6024. (n) Bartoli, G.; Bosco, M.; Carlone, A.; Cavalli, A.; Locatelli, M.; Mazzanti, A.; Ricci, P.; Sambri, L.; Melchiorre, P. Angew. Chem. Int. Ed. 2006, 45, 4966. (o) Wang, Y.; Liu, X.; Deng, L. J. Am. Chem. Soc. 2006, 128, 3928. (p) Li, H.; Wang, B.; Deng, L. J. Am. Chem. Soc. 2006, 128, 732. (q) Shi, M.; Lei, Z. Y.; Zhao, M. X.; Shi, J. W. Tetrahedron Lett. 2007, 48, 5743. (r) Ogawa, S.; Shibata, N.; Inagaki, J.; Nakamura, S.; Toru, T.; Shiro, M. Angew. Chem. Int. Ed. 2007, 46, 8666. (s) Xu, X.; Wang, K.; Nelson, S. G. J. Am. Chem. Soc. 2007, 129, 11690. (t) Cheng, L.; Liu, L.; Jia, H.; Wang, D.; Chen, Y. J. J. Org. Chem. 2009, 74, 4650. (u) Liu, Y.; Sun, B.; Wang, B.; Wakem, M.; Deng, L. J. Am. Chem. Soc. 2009, 131, 418.

(13) Aliphatic $\alpha$-keto esters such as ethyl 2-cyclohexyl-2-oxoacetate were also used, but only gave $59 \%$ ee.

(14) See the Supporting Information for details.

(15) For selected examples of the interaction pattern between the thiourea moieties and $\alpha$-keto esters, see: (a) Wang, F.; Liu, X. H.; Cui, X.; Xiong, Y.; Zhou, X.; Feng, X. M. Chem. Eur. J. 2009, 15, 589. (b) Li, W. Y.; Huang, D. F.; Lv, Y. J. Org. Biomol. Chem. 2013, $11,7497$.

(16) General Procedure for the Synthesis of Chiral Oxazoline: Phenylglyoxylate (1; $0.1 \mathrm{mmol})$, tert-butyl isocyanoacetate (2d; $11.9 \mathrm{mg}, 0.12 \mathrm{mmol})$ and bifunctional catalyst $\mathbf{3 c}(5.9 \mathrm{mg}, 0.01$ mmol) were stirred in toluene $(0.5 \mathrm{~mL})$ at $26{ }^{\circ} \mathrm{C}$ for $24 \mathrm{~h}$. The mixture was separated by silica gel chromatography $(10 \%$ EtOAc/petroleum ether) and gave product 4. 
Analysis data for compound 4a: ${ }^{1} \mathrm{H}$ NMR $\left(400 \mathrm{MHz}, \mathrm{CDCl}_{3}\right): \delta=$ $1.20-1.24(\mathrm{~m}, 3 \mathrm{H}), 1.52$ (s, $9 \mathrm{H}), 4.11-4.24(\mathrm{~m}, 2 \mathrm{H}), 4.88$ (d, $J=$ $2.0 \mathrm{~Hz}, 1 \mathrm{H}), 7.14(\mathrm{~d}, J=2.0 \mathrm{~Hz}, 1 \mathrm{H}), 7.31-7.56(\mathrm{~m}, 2 \mathrm{H}), 7.58-$ $7.60(\mathrm{~m}, 2 \mathrm{H}) .{ }^{13} \mathrm{C}$ NMR $\left(100 \mathrm{MHz}, \mathrm{CDCl}_{3}\right): \delta=14.0,28.0,62.5$, 79.7, 83.0, 89.4, 125.3, 129.0, 138.7, 155.5, 168.2, 168.6. HPLC
(Chiralcel IB, hexane $/ i$-PrOH $=95: 5$, flow rate: $1.0 \mathrm{~mL} / \mathrm{min}, \lambda=$ $210 \mathrm{~nm}): t_{\mathrm{R}}($ major $)=18.08 \mathrm{~min}, t_{\mathrm{R}}($ minor $)=20.22 \mathrm{~min}$. ESIHRMS: $m / z[\mathrm{M}+\mathrm{H}]$ calcd for $\mathrm{C}_{17} \mathrm{H}_{21} \mathrm{NO}_{5}$ : 320.1498; found: 320.1492 . 